\title{
INTERMITTENT HEMODIALYSIS, AN ALTERNATIVE TREATMENT FOR OVINE WITH ACUTE-ON-CHRONIC KIDNEY DISEASE
}

\author{
Priscylla Tatiana Chalfun Guimaraes Okamoto ${ }^{1}$ \\ Ana Luísa Holanda de Albuquerque ${ }^{2}$ \\ Silvano Salgueiro Geraldes ${ }^{3}$ \\ André Nanny Le Sueur Vieira ${ }^{3}$ \\ Alessandra Melchert ${ }^{1}$ \\ Maria Lúcia Gomes Lourenço ${ }^{1}$ \\ Carmel Rezende Dadalto ${ }^{3}$ \\ Amanda Sarita Cruz Aleixo ${ }^{3}$ \\ Maria Gabriela Picelli de Azevedo ${ }^{3}$ \\ Diana do Nascimento ${ }^{4}$ \\ Thaís Gomes Rocha ${ }^{1}$
}

\begin{abstract}
Chronic Kidney Disease (CKD) is a syndrome composed of numerous comorbidities such as the failure of excretion of toxins and nitrogenous compounds from metabolism, as well as the failure to maintain endocrine, water, electrolyte and acid-base homeostasis in all mammals. As it is a non-regenerative and progressive disease, any endogenous or exogenous insults in the organ in question will lead to the intensification of all these mentioned disorders associated with decreased urinary output. Several studies in humans and animals recommend the use of renal replacement therapy, especially in those who already have CKD, and who are in uremic syndrome. This report aims to demonstrate that the use of intermittent hemodialysis (HI) in sheep is a therapeutic alternative in those in renal failure. A six-year-old Bergamasca sheep was presented with lateral decubitus, dyspnea, dark liquid diarrhea, apathy, anorexia and pulmonary crepitation on auscultation. Laboratory tests showed azotemia and electrolyte changes such as hypocalcemia, hypokalemia, hypochloremia, isosthenuria $(1,012)$, pyuria, glycosuria, and a protein: creatinine ratio of 0.88 . In ultrasonography, the real resistivity index was above 0.54 , being suggestive of loss of renal perfusion. The treatment chosen consisted of electrolytic and fluid replacement, associated with HI. After HI, the sheep showed great clinical and laboratory improvement as expected, however, despite not having survived, the histopathological findings of the necropsy pointed out segments of glomerulosclerosis, thus reinforcing the hypothesis that the animal already had a CKD which was aggravated due to the association of hypovolemia, hypotension by anesthetic drugs and the indiscriminate use of NSAIDs. Despite the death of the sheep, HI again proved to be a therapy of rapid clinical and laboratory improvement of the patient compared to conventional clinical treatment, thus being an important treatment alternative for sheep with a high impact on reproduction, production, and research.
\end{abstract}

Key words: ovine, renal, dialysis

\footnotetext{
${ }^{1}$ Docente da Faculdade de Medicina Veterinária e Zootecnia - UNESP-Botucatu-SP Correspondência: tatiana.okamoto@unesp.br

2 Mestrado em Medician Veterinária. Faculdade de Medicina Veterinária e Zootecnia - UNESP, Botucatu. luisahdealbuquerque@gmail.com

${ }^{3}$ Doutorando em Medicina Veterinária. Faculdade de Medicina Veterinária e Zootecnia - UNESP, Botucatu. silvanoport@hotmail.com

${ }^{4}$ Residencia Médica na Faculdade de Medicina Veterinária e Zootecnia - UNESP, Botucatu. d.nascimento@ unesp.br
}

Okamoto PTCG, Albiquerque, ALH, Geraldes SS, Vieira ANLS, Melchert A. Lourenço MLG. Intermittent hemodialysis, an alternative treatment for ovine with Acute-on-Chronic Kidney disease. Vet. e Zootec. 2020; 27 : 001-014. 


\title{
HEMODIÁLISE INTERMITENTE, UM TRATAMENTO ALTERNATIVO PARA OVINOS EM DOENÇA RENAL CRÔNICA AGUDIZADA.
}

\begin{abstract}
RESUMO
A Doença Renal Crônica (DRC) é uma síndrome composta por inúmeras comorbidades como a falha da excreção de toxinas e compostos nitrogenados oriundos do metabolismo, bem como da falha na manutenção da homeostase endócrina, hídrica, eletrolítica e ácido-básico de todos os mamíferos. Por ser uma doença não-regenerativa e progressiva, quaisquer insultos endógenos ou exógenos no órgão em questão propiciará a intensificação de todas estas desordens mencionadas associadas a diminuição do débito urinário. Diversos estudos em humanos e animais recomendam o emprego de terapia de substituição renal, especialmente naqueles que já apresentam a DRC, e que se encontram em síndrome urêmica. Este relato tem como objetivo demonstrar que o emprego da hemodiálise intermitente (HI) em ovinos é uma alternativa terapêutica naqueles em falência renal. Uma ovelha Bergamácia de seis anos foi encaminhada em decúbito lateral, dispneia, diarreia líquida escura, apatia, anorexia e crepitação pulmonar à auscultação. Exames laboratoriais demonstraram azotemia e alterações eletrolíticas como hipocalcemia, hipocalemia, hipocloremia, isostenúria (1.012), piúria, glicosúria, e razão proteína: creatinina de 0,88. Em ultrassonografia, o index de resistividade real, apresentou-se acima de 0,54 , sendo sugestivo de perda de perfusão renal. O tratamento eleito constituiu na reposição eletrolítica e volêmica, associada a HI. Após a HI, a ovelha apresentou grande melhora clínica e laboratorial como esperado, no entanto, apesar de não ter sobrevivido, os achados histopatológicos da necropsia apontaram segmentos de glomeruloesclerose, reforçando assim a hipótese de que o animal já apresentava uma DRC a qual agudizou devido a associação da hipovolemia, hipotensão por fármacos anestésicos e ao uso indiscriminado de AINES. Apesar do óbito da ovelha, a HI demonstrou novamente ser uma terapia de rápida melhora clínica e laboratorial do paciente comparada ao tratamento clínico convencional, assim sendo uma importante alternativa de tratamento para ovinos com alto impacto na reprodução, produção e pesquisa.
\end{abstract}

Palavras-chave: ovino, diálise, renal.

\section{HEMODIALISIS INTERMITENTE, UN TRATAMIENTO ALTERNATIVO PARA OVINOS CON ENFERMEDAD RENAL AGUDA EN CRÓNICA.}

\section{RESUMEN}

La enfermedad renal crónica (ERC) es un síndrome compuesto por numerosas comorbilidades, como el fracaso de la excreción de toxinas y compuestos nitrogenados del metabolismo, así como el fracaso para mantener la homeostasis endocrina, hidrica, electrolitica y ácido-base en todos los mamíferos. Como es una enfermedad no regenerativa y progresiva, cualquier insulto endógeno o exógeno en el órgano en cuestión conducirá a la intensificación de todos estos trastornos mencionados asociados con la disminución del gasto urinario. Varios estudios en humanos y animales recomiendan el uso de la terapia de reemplazo renal, especialmente en aquellos que ya tienen ERC y que padecen síndrome urémico. Este informe tiene como objetivo demostrar que el uso de hemodiálisis intermitente (HI) en ovejas es una alternativa terapéutica en aquellos con insuficiencia renal. Una oveja Bergamasca de seis años fue apresentada en decúbito lateral, disnea, diarrea líquida oscura, apatía, anorexia y crepitación pulmonar en la auscultación. Las pruebas de laboratorio mostraron alteraciones de azotemia y electrolitos como hipocalcemia, hipocalemia, 
hipocloremia, isostenuria $(1,012)$, piuria, glucosuria y una relación proteína: creatinina de 0.88. En la ecografía, el índice de resistividad real fue superior a 0,54 , lo que sugiere una pérdida de perfusión renal. El tratamiento elegido consistió en reemplazo electrolítico y de fluidos, asociado con HI. Después de HI, la oveja mostró una gran mejoría clínica y de laboratorio como se esperaba, sin embargo, a pesar de no haber sobrevivido, los hallazgos histopatológicos de la necropsia señalaron segmentos de glomeruloesclerosis, lo que refuerza la hipótesis de que el animal ya tenía una ERC que se agravó debido a la asociación de hipovolemia, hipotensión por fármacos anestésicos y el uso indiscriminado de AINE. A pesar de la muerte de la oveja, HI nuevamente demostró ser una terapia de rápida mejora clínica y de laboratorio del paciente en comparación con el tratamiento clínico convencional, por lo que es una alternativa de tratamiento importante para las ovejas con alto impacto en la reproducción, producción e investigaciónes clinicas.

Palabras clave: ovino, renal, diálisis.

\section{INTRODUCTION}

The kidney is responsible for many vital functions such as excretion of metabolites, homeostasis of fluid, electrolyte and acid-base imbalances, and also has its own endocrine production and regulation (1). The rapid loss of renal function results in the accumulation of endogenous and exogenous toxic substances and following by the reduction of urine output as defined by oliguria, which, if not early corrected, damages distant organ systems (1). Chronic kidney disease (CKD) may be exacerbated, presenting as a sudden decline in renal function and acute kidney injury (AKI) symptomatology; Therefore, acute kidney injury (AKI) is an important disease characterized by an acute decline in kidney function (2).

Intermittent hemodialysis $(\mathrm{IH})$ is a valuable extracorporeal therapy modality that aims at the correction of increased concentrations of water-soluble toxins and other soluble metabolites as a consequence of renal failure (3). Intermittent hemodialysis is commonly prescribed as a renal replacement therapy in cases of AKI, acute-on-chronic kidney disease, chronic kidney disease, and intoxications (4). Therefore, a careful and precise understanding of AKI in domestic animals in association with the punctual prescription of IH can offer better opportunities for kidney resuscitation, and improvement of clinical signs due to the impairment of toxins excretion (2). Hence, this case report is related to the prescription of $\mathrm{IH}$ in an ewe with acute-on-chronic disease that was irresponsive to conventional treatment due to anesthetic procedure for embryo transfer.

\section{CASE REPORT}

A six-years old Bergamasca ewe was admitted to the Veterinary Teaching Hospital in lateral recumbency and dyspnea. Although there was no information regarding previous exams before the procedure, the animal had been subjected to a laparoscopic procedure for embryo transfer with anesthetic and anti-inflammatory protocol: diazepam (Compaz ${ }^{\circledR}$, Cristalia, $0.5 \mathrm{mg} / \mathrm{Kg}$, IV, single dose), meloxicam (Meloxicam, Eurofarma, $0.5 \mathrm{mg} / \mathrm{Kg}$, IV, single dose), and morphine (Dimorf ${ }^{\circledR}$, Cristalia, $0.2 \mathrm{mg} / \mathrm{Kg}$, IV, single dose).

On the following day, the animal presented persistent recumbency, condition scoring of sheep classified as $1 / 5$, anorexia, mucous membranes were pink but dry, lymph nodes were normal by size, mobility and temperature, dehydration was staged at $7 \%$. Its heart rate was 120 beats/min, and respiratory rate was 20 movements/min with inspiratory dyspnea, rectal temperature of $38.5^{\circ} \mathrm{C}$, and presence of ruminal atony.

Okamoto PTCG, Albiquerque, ALH, Geraldes SS, Vieira ANLS, Melchert A. Lourenço MLG. Intermittent hemodialysis, an alternative treatment for ovine with Acute-on-Chronic Kidney disease. Vet. e Zootec. 2020; 27 : 001-014. 
Complimentary exams achieved were complete blood count (CBC) with fibrinogen analysis, serum biochemistry, urinalysis and blood gas analysis. Blood and serum biochemical analysis revealed altered results (Table 1).

According to laboratorial findings, and to the suspected diagnosis of hypocalcemia and dehydration, our clinical conservative treatment consisted of fluid therapy for rehydration with a ringer lactate solution with a rate of $40 \mathrm{~mL} / \mathrm{kg} / \mathrm{day}$, and intravenous continuous infusion of calcium borogluconate (Calfort ${ }^{\circledR}$, VilaVet Saúde Animal LTDA, $0.5 \mathrm{~mL} / \mathrm{kg}$, single dose). Forty minutes after, the ewe recovered from its treatment, stood up and presented appetite.

The ewe received the same treatment for two days and was clinically well until the third day, when the animal presented dark liquid diarrhea, dullness, anorexia, pulmonary crackles and remained most of the time on sternal recumbency, abnormalities were found in laboratorial exams, described in table 1.

Ultrasonography exam revealed both kidneys were symmetric, with regular and welldefined edges, preserved cortical-medullar definition with slightly increase of renal cortical area, distorting cortico-medullar relation (Figure 1). Cortical had increase echogenicity maintaining homogeneous echotexture. There were no signs of nephrolithiasis or hydronephrosis. Bilateral pyelectasis measuring $0,2 \mathrm{~cm}$ was registered. Sagittal measure of the right kidney was $7,22 \mathrm{~cm}$, and left $7,80 \mathrm{~cm}$. The US also allows the evaluation of resistivity index (RI) values. To evaluate the renal parenchyma perfusion, the resistivity index (RI) of the interlobar artery is measured through the systolic velocity peak and final diastolic velocity in spectral layout with pulsing doppler. A study with 30 adult sheep describes kidney's abnormal perfusion related to RI above 0.54 , being possible that this sheep had already loss of renal perfusion (5).

Table 1. Abnormal laboratorial exams prior to IH treatment.

Abnormal laboratorial exams

Day $1 \quad$ Hyperfibrinogenemia $(600 \mathrm{mg} / \mathrm{dL}$; ref: 200 - 500), hypoalbuminemia $(1.9 \mathrm{~g} / \mathrm{dL}$; ref: 2.4 - 3), BUN (116.2 mg/dL; ref: 3-10), serum creatinine (17.7 mg/dL; ref: 70$105)$, blood glucose (208 mg/dL; ref: 25 - 50), serum phosphorus $(16.2 \mathrm{mg} / \mathrm{dL}$; ref: $1.62-2.36)$ and total calcium $(3.13 \mathrm{mg} / \mathrm{dL}$; ref: $2.88-3.20)(6)$.

Day 3 Serum biochemistry of the third day indicated azotemia $(177.34 \mathrm{mg} / \mathrm{dL}$ of BUN and $25 \mathrm{mg} / \mathrm{dL}$ of creatinine). Urinalysis was performed by catheterism, which revealed a turbid pink urine with isosthenuria (1.012), pyuria and glycosuria. Urinary protein: creatinine ratio was 0.88 . Additionally, urinary output of the first 12 hours was recorded and revealed urine output $>2 \mathrm{ml} / \mathrm{Kg}$ per hour. Ultrasound imaging evaluated RI 0.64 and 0.63 to right and left kidneys, respectively, being possible that this sheep had already loss of renal perfusion.

Day $9 \quad$ Hypokalemia of $3.88 \mathrm{mEq} / \mathrm{L}$ (reference: $3.9-5.4 \mathrm{mEq} / \mathrm{L}$ ). Mild hypochloremia of

Prior to first IH $91 \mathrm{mmol} / \mathrm{L}$ (reference: $95-103 \mathrm{mmol} / \mathrm{L}$ ). Serum BUN concentration (185.27 $\mathrm{mg} / \mathrm{dL}$ ) has presented higher values than the previous exam, serum creatinine was $23 \mathrm{mg} / \mathrm{dL}$, there was also hyperfibrinogenemia through heat precipitation method (7) of $800 \mathrm{mg} / \mathrm{dL}(100-500 \mathrm{mg} / \mathrm{dL})$ suggesting an inflammatory process, and CBC has revealed a mild leukocytosis 15.1 x $1000 / \mu \mathrm{L}(4-12 \times 1000 / \mu \mathrm{L})$ with neutrophilia (76\%). Echocardiogram revealed moderate mitral insufficiency with overload of left chambers, left ventricular hypertrophy and presence of hyperechogenic content adhered to the atrium wall. Thoracic radiography reveled opacification of pulmonary fields with alveolar pattern in cranial lobe and bronchial pattern in the remaining pulmonary area.

As protocol to initiate $\mathrm{IH}$ therapy, an echocardiogram and a thoracic radiographic examination were performed. Echocardiogram revealed moderate mitral insufficiency with 
overload of left chambers, left ventricular hypertrophy and presence of hyperechogenic content adhered to the atrium wall. Thoracic radiography reveled opacification of pulmonary fields with alveolar pattern in cranial lobe and bronchial pattern in the remaining pulmonary area.

Prior to the prescription of $\mathrm{IH}$, blood gas, serum BUN and creatinine, and another blood work were done. All dialysis sessions were performed with a $4008 \mathrm{~S}$ Fresenius machine (Fresenius Medical Care ${ }^{\circledR}$ ). The ewe was catheterized with a 12 French double-lumen 68 catheter $\left(\right.$ VetMedical $\left.^{\circledR}\right)$ in the right jugular vein. For dialysis prescription and adequacy, an algorithm based on the urea reduction ratio (URR) $(3 ; 8)$, based on small animal practice was used and hemodialyzers (Hemoflow F8, Fresenius Medical Care ${ }^{\circledR}$ ) were chosen according to the patient's body weight and BUN concentrations. A bicarbonate solution (BiBag, Fresenius Medical Care ${ }^{\circledR}$ ) was added to the dialysate solution and kept in a constant flow rate (Qd) of $500 \mathrm{~mL} / \mathrm{min}$ in all sessions. All lines and dialyzers received a priming solution of sterile saline.

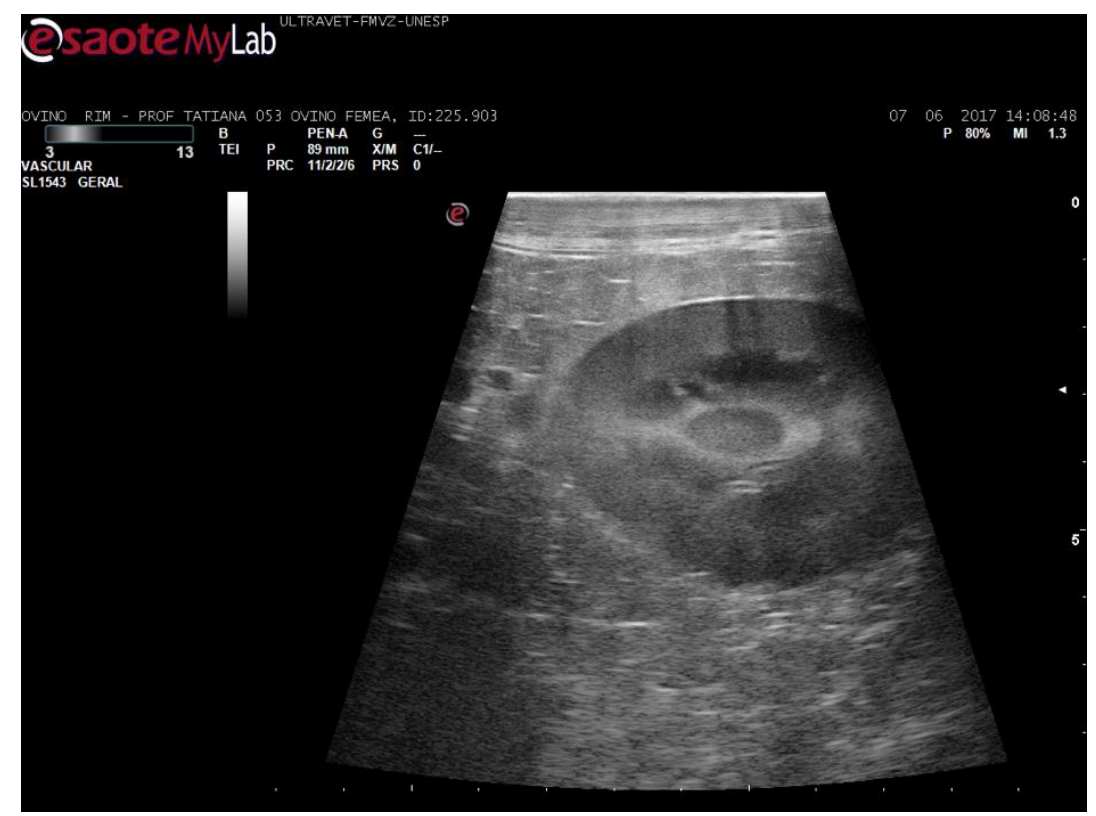

Figure 1. Mode-B ultrasonographic image: maintenance of corticomedullar relation with hyperechogenicity of the kidney's cortex.

During $\mathrm{IH}$, urea reduction rate (URR) should be evaluated as the dialyzer accomplishes the blood clearance and should be higher than $75 \%$ to improve survival (8), URR is also used as a measure of dialysis adequacy in people and in small animals (3), its formula is calculated as:

$$
\operatorname{URR}(\%)=\frac{\left(B U N_{\text {pre }}-B U N_{\text {post }}\right)}{B U N_{\text {pre }}}
$$

According to the individual needs of the ewe, blood flow (Qb) and ultrafiltration (UF) rates were kept constant between 75 to $125 \mathrm{~mL} / \mathrm{min}$ and 5 to $15 \mathrm{~mL} / \mathrm{kg} / \mathrm{h}$ respectively. Anticoagulation was achieved by fractionated heparin (Liquemine, Roche $\AA$ ) with an initial dose of $60 \mathrm{UI} / \mathrm{kg} / \mathrm{IV}$. An activated clotting time (ACT) machine (MCA 200080 - Fundação Adib Jatene) was used to measure the anticoagulant effect hourly and extra boluses of heparin were applied if necessary. Systolic blood pressure was also monitored by Doppler (Parks 82 Medical Electronics Ultrasonic Doppler Flow Detector 811-B) every 30 minutes throughout the dialysis treatment. Individual conditions such as Qb, Qd, UF, and heparin dose were kept stable throughout the study period except for mild hypotension on the third session. During 
first $\mathrm{IH}$ there were continuous flow interruptions after 120 minutes and because of clot formation in the bubble tasting the $\mathrm{IH}$ ended at $2 \mathrm{~h} 40 \mathrm{~min}$, during second $\mathrm{IH}$ there was an interruption because of inadequate flow.

The first session of dialysis happened after 9 days of hospitalization, endured for 200 minutes with a URR of $41 \%$ (Table 1) at the end of the session (Figure 2). Additionally, after its dialytic treatment, the ewe had improved its clinical signs, the sheep was bright and has presented appetite. On the following day, day 10 of hospitalization, a second session of 180 min was performed with an URR of $52 \%$. A control echocardiogram was done after second dialysis session, which revealed a decrease in the systolic function and pulmonary artery flow, reduction of left chambers diameter, aggravation of left ventricular hypertrophy and enlargement of left atrioventricular valve's cuspids. Despite its worsening of cardiac function, the ewe has remained stable for the next two days without IH treatment.

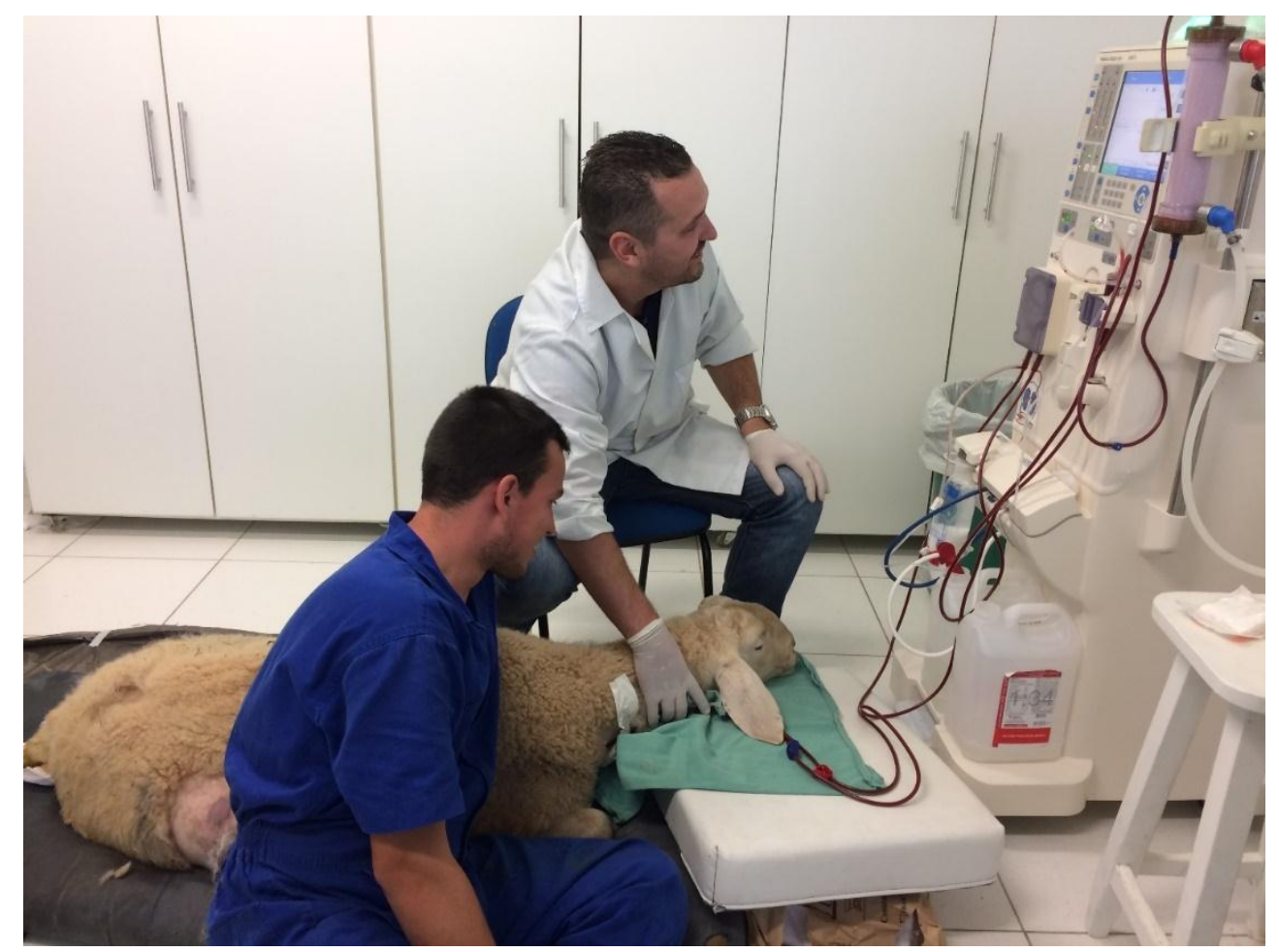

Figure 2. Sheep during intermittent hemodialysis treatment.

A third session of hemodialysis was performed on day 13 of hospitalization, after with a URR of 50\% (Table 2). In spite of clinical improvement and relevant decrease of serum BUN and creatinine (Table 2), the animal presented sudden death at the end of the day.

Table 2. Values of serum urea and creatinine, and urea reduction ratio (URR) Pre and Postdialysis treatment.

\begin{tabular}{lcccc}
\hline Session & Moment & $\begin{array}{c}\text { Serum Urea } \\
(\mathbf{m g} / \mathbf{d L})\end{array}$ & $\begin{array}{c}\text { Serum Creatinine } \\
(\mathbf{m g} / \mathbf{d L})\end{array}$ & URR (\%) \\
\hline \multirow{2}{*}{ 1st (day 9*) } & Pre-IH & 397 & 23 & $41 \%$ \\
& Post-IH & 104.54 & 14.14 & \\
2nd (day 10*) & Pre-IH & 117.93 & 1.9 & $52 \%$ \\
& Post-IH & 118 & 5.41 & \\
3rd (day 13*) & Pre-IH & 206 & 7.3 & $50 \%$ \\
\hline
\end{tabular}

*Days of hospitalization

Okamoto PTCG, Albiquerque, ALH, Geraldes SS, Vieira ANLS, Melchert A. Lourenço MLG. Intermittent hemodialysis, an alternative treatment for ovine with Acute-on-Chronic Kidney disease. Vet. e Zootec. 2020; 27 : 001-014. 
Necropsy macroscopic findings were suggestive of expressive interstitial glomerulonephritis, considering its pale cortex, red-colored corticomedullary junction and radial pale striations (Figure 3). Microscopically, there was marked kidneys fibrosis with chronic cardiac infarct. Histopathology unveiled marked interstitial fibrosis, protein-like material in the tubules, intra-tubular calcification, accentuated glomerulosclerosis, discrete glomerulonephritis and thickening of the Bowman capsule (Figure 3 and 4). In addition, myocardium and auricles had whitish diffuse spots, mitral valve was slightly thickened and opaque, tricuspid was also opaque. Left cardiac muscle and tricuspid had degenerated muscular fibers, focus of fibrosis tissue (chronic infarct) and adipose tissue, moderate vacuolization of myocytes and discreet mononuclear infiltrate in myocardium; right cardiac muscle had moderate muscular fibers atrophy. There was also pulmonary emphysema, cystitis and jejunitis.
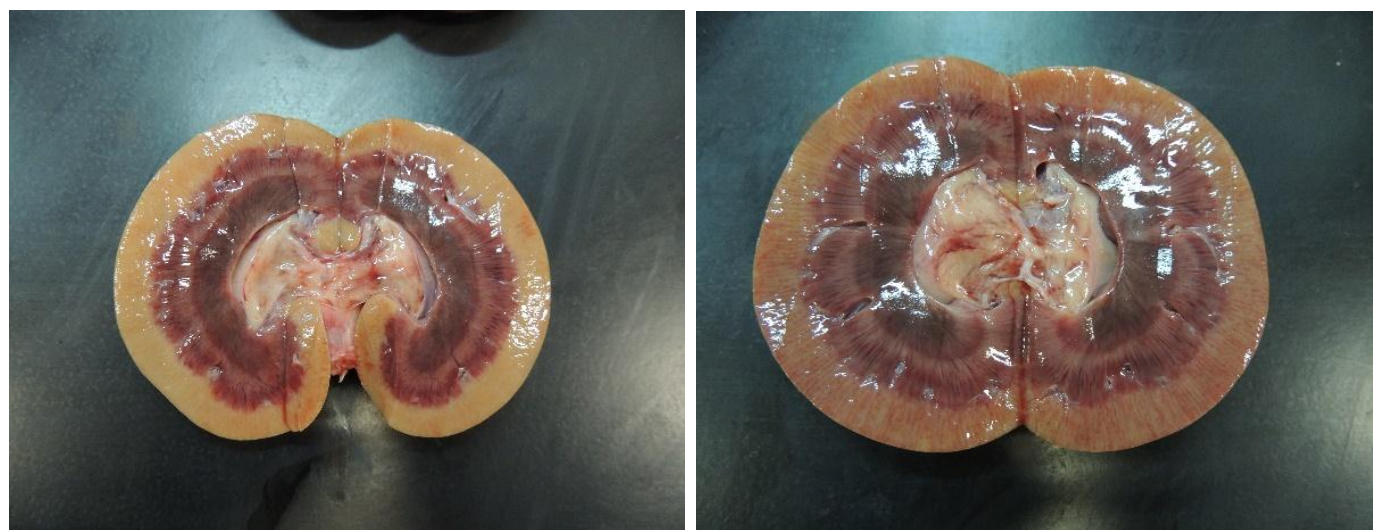

Figure 3. Left and right kidneys with pale cortex, red-colored corticomedullar junction and radial pale striations. 


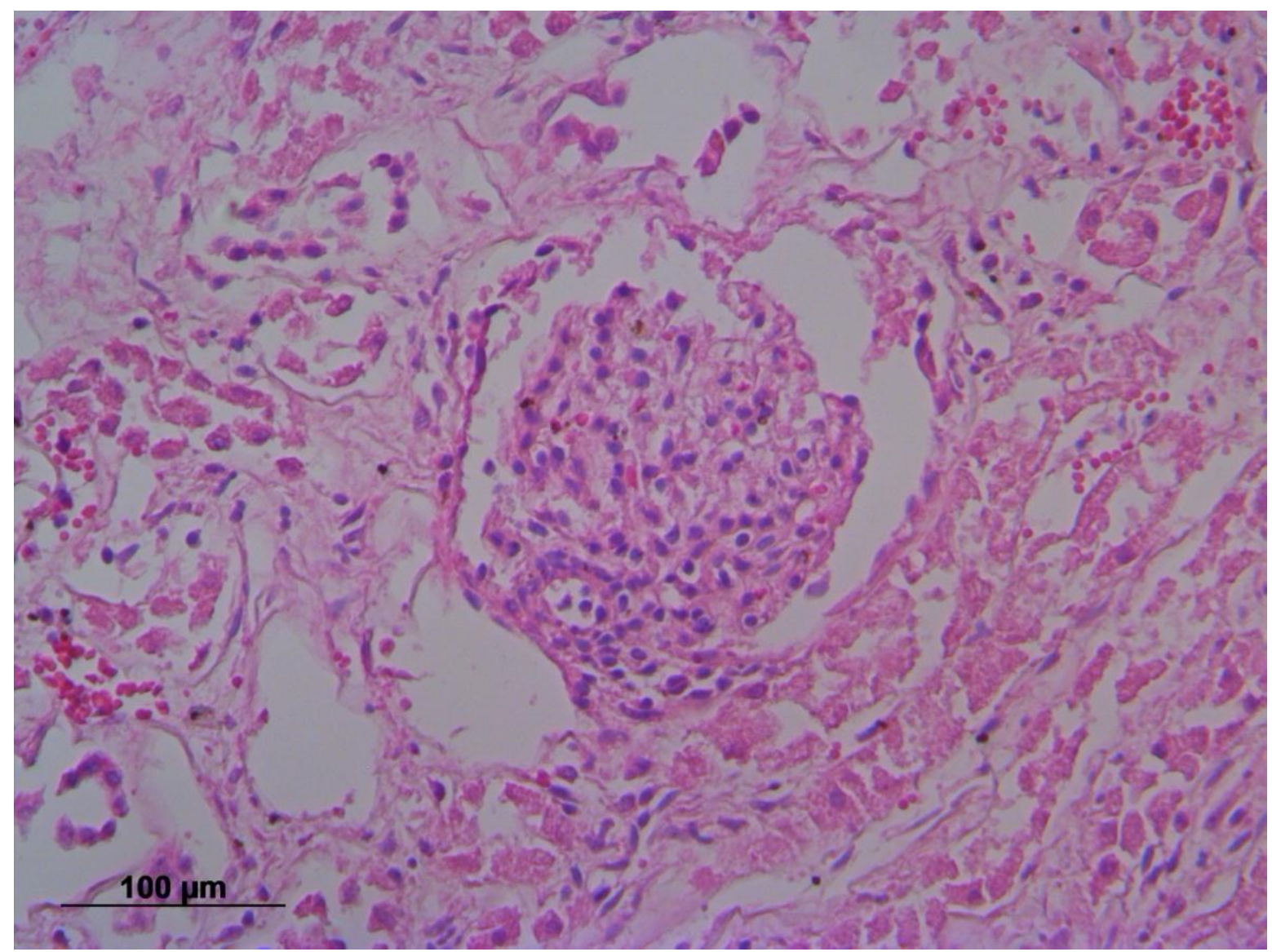

Figure 4. Glomerular histopathology showing glomerulonephritis

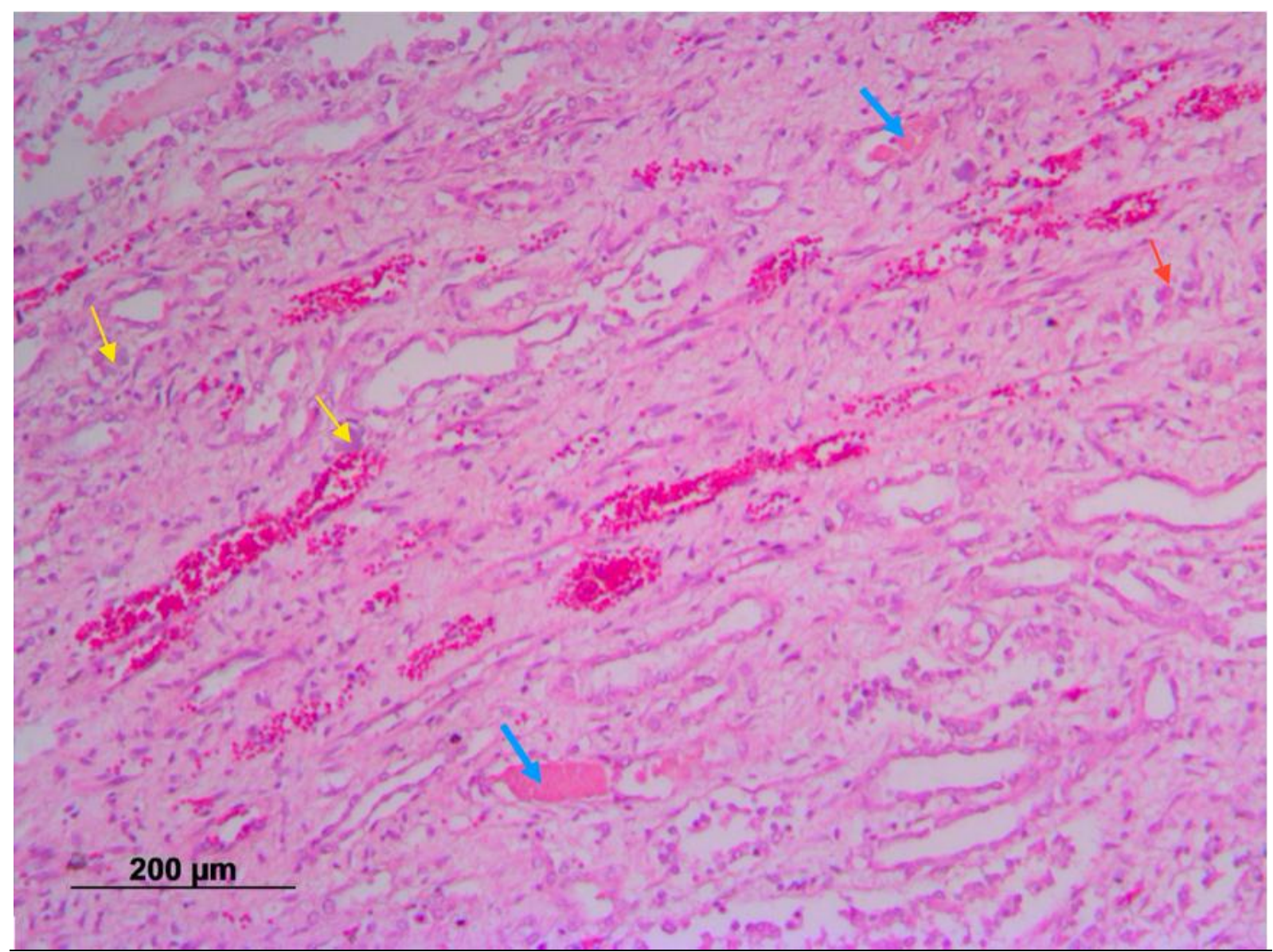

Okamoto PTCG, Albiquerque, ALH, Geraldes SS, Vieira ANLS, Melchert A. Lourenço MLG. Intermittent hemodialysis, an alternative treatment for ovine with Acute-on-Chronic Kidney disease. Vet. e Zootec. 2020; 27: 001-014. 
Figure 5. Kidney's histopathology: protein fibrosis and calcification. Blue arrow: protein, yellow arrow: calcification, and red arrow: fibrosis.

\section{DISCUSSION}

Renal failure still is the cause of high morbidity and mortality in human medicine and in domestic animals. In a recent study by Bujok and colleges (9) they have treated ewes as a study model to enhance renal replacement therapy. Compared to smaller domestic animals, the sheep has some advantages such as its similar size to human's, and similarity in its coagulation system; additionally, when compared to pigs or dogs, they are beneficial due to its anatomical neck features that facilitate venous access to the jugular vein (9).

Acute Renal Injury has multiple pathophysiology mechanisms such as renal infarction and ischemia by hypovolemia, myoglobinuria, hemoglobinuria, leptospirosis and other infectious diseases, vasculitis, neoplasia, urolithiasis, and toxic nephropathies by aminoglycosides, non-steroidal antiinflammatory drugs (NSAIDs), heavy metals, vitamin D toxicosis and many other exogenous and endogenous insults (4,10-12). Although urolithiasis is common in sheep, cases of AKI are unusual.

In large animals, the nutrition of the patient is essential to be observed, especially the nutritional values of the protein. Low-protein diets increase the fractional absorption of BUN from urine at low rates (13); However, in this case, the ewe has received the same balanced diet for years without previous history of renal injury. Therefore, we hypothesized that the ewe has developed AKI after the combination of the anesthetic procedure associated with NSAIDs in an undiagnosed patient with pre-existing chronic kidney disease (CKD) associated with cardiomyopathy, leading to hypovolemic depression and hypotension by the anesthetics.

The ultrasonographic exam allows an early diagnosis of CKD prior to the presence of azotemia (14). This exam has been widely used to evaluate the genitourinary tract (15-17). Notwithstanding, in this report, there was no finding by the ultrasonographic exam that could indicate presence of CKD, such as in its architecture abnormality, parenchyma irregularity and altered corticomedullar definition (18). Being its kidney's size within normality values for the species (5), a higher enhance of renal echogenicity was observed in the ewe is a nonspecific finding in animals with $\mathrm{AKI}$ or $\mathrm{CKD}$, usually as a consequence of an interstitial or glomerular nephritis, nephrosis or acute tubular necrosis (18).

The diagnosis of AKI commonly results in the association of clinical and laboratorial findings (4). Measurements of serum creatinine concentrations is frequent, but it must reach a peak and remain steady to reflect renal function, also since it is a muscle metabolite breakdown product, its serum concentration might be underestimated in low-muscle animals and overestimated in muscled ones, not to mention that age, gender and breed might have influence as it does in humans (19). In this report, the sheep had a low-muscle condition scoring classified as 1 of 5. On the other hand, the International Renal Interest Society (IRIS) has updated the definitions of AKI based on fast change of serum creatinine concentrations. The increase of $0.3 \mathrm{mg} / \mathrm{dL} / 48 \mathrm{~h}$ in a nonazotemic patient is now stated as AKI grade I in small animals (20). Furthermore, the assessment of serum BUN combined with serum creatinine concentrations defines the azotemia state being an indicative of an AKI when pre and postrenal azotemia are excluded by other complementary exams (21).

Urinalysis is a practical, resourceful, and cheap exam, its evaluation consists of physical and chemical analysis from freshly collected urine (less than 1 hour). Furthermore, is important to considerer the urine collection technique because natural micturition may carry bacteria, leukocytes, and epithelial cells confounding its diagnosis (22). The ewe's urine was collected by catheterization, which revealed turbid pink urine with isosthenuria (1.012), pyuria and glycosuria.

Okamoto PTCG, Albiquerque, ALH, Geraldes SS, Vieira ANLS, Melchert A. Lourenço MLG. Intermittent hemodialysis, an alternative treatment for ovine with Acute-on-Chronic Kidney disease. Vet. e Zootec. 2020; 27 : 001-014. 
Another complementary test is the ratio between urinary protein and creatinine excretion. Creatinine depuration through the urinary system is relatively constant and, when decreased, is the result of a lower protein glomerular filtration rate, since creatinine crosses the glomerular filtration barrier more easily than protein (23). Reference values are not available for sheep, but in dogs, the diagnosis of proteinuria consists in a protein: creatinine excretion rate above 0.5 (24). The ewe's urinary protein: creatinine ratio was 0.88 , and despite the absence of references for sheep, and considering reference values for small animals (24), this sheep had diagnosis of proteinuria. There are more sensitive diagnostic methods, such as renal biomarkers (25), but it's availability in Veterinary Medicine is still very limited. Additionally, the decrease of serum albumin concentrations is expected in kidney diseases and is co-related to a poor prognosis, as the case reported $(2,12)$.

Hyperkalemia and hyperphosphatemia are both electrolyte imbalances commonly described in AKI of humans, and domestic animals due to tubular failure of potassium and phosphate excretion $(4,20)$. The ewe presented an increase in serum potassium concentration before the first dialytic session, and potassium levels were decreased after it (Table 2).

Moreover, it is important to attempt the volume status of the patient and its urinary output (4). The prescription of fluid therapy in animals with AKI is important at the first 24 hours to correct pre-renal azotemia effects due to dehydration and hypovolemia. However, the correction of dehydration, maintenance and of fluid losses such as vomiting and diarrhea must be precisely calculated to avoid fluid overload and worsening kidney function (20). In small animals, urinary output varies between 1 to $2 \mathrm{~mL} / \mathrm{Kg} /$ hour after previous rehydration (26), although there's no specific references for sheep urinary output, one study described the urinary output of 16 ewes with 3 to $4.5 \mathrm{~mL} / \mathrm{kg} / \mathrm{h}$ (27), demonstrating that the sheep also had its values within the limits.

Intermittent hemodialysis is renal replacement therapy highly recommended in humans and animals with underlying AKI (4). The main principles of IH are diffusion, convection and absorption and its efficiency depend on the solute characteristics, on the dialyzer's pore size, in its fluid change magnitude, and other structural characteristics (2). The diffusion principle is the most important, because of its effectiveness in removing of light-weight water-soluble molecules such as BUN, creatinine, sodium, potassium, phosphorus, and magnesium by solute movement from areas of high concentration to areas of low concentration, defined as the concentration gradient of the solute and the kinetic energy of the solution (mostly molecular weight) (2).

During convection, water is removed along with the solutes, blood is exposed to a positive pressure membrane that ultrafilters fluid and dissolves solute into the dialyzer, rejecting molecules of low and medium molecular weight (9). To eliminate molecules of high molecular weight, and protein-bound or lipid solute toxins, blood must be exposed to an adsorbent which binds toxins (12).

There is no conventional therapy as efficient as intermittent hemodialysis to regulate cumulative biochemical, acid-base and electrolytic balance. Moreover, supportive treatment is extremely important in order to keep hydric, electrolyte, and acid-base balance (2). Bujok and collegues (9) have described the efficiency and applicability of $\mathrm{IH}$ in sheep submitted to bilateral nephrectomy. In fact, markedly clinical and laboratorial improvement was noticed in this report shortly after every IH session, the ewe could stand, walk and present appetite, otherwise it would stay in permanent recumbency and anorexic. The decrease of azotemia along with electrolytes readjustment are described in Tables 1 and 2.

However, since IH activates the immunologic system and coagulation cascade, it contributes to inflammation, occurrence of oxidative stress, and homeostasis disorders (9). IH can lead changes in blood volume, altering the blood flow and its intravascular pressure (28), which can be harmful to a cardiopathic patient such as the sheep reported. Also, heparin use 
in IH to prevent clot formation within the dialyzer may also contribute to decrease platelet count, although there was no sign of thrombocytopenia in the sheep reported (11). One study reported technical complications of dialysis (water-induced hemolysis) and intractable pulmonary edema accounted for the shorter survival of the dialyzed sheep (29), no complications alike were reported here since the dialysis water is regularly analyzed.

Cardiovascular disease is the main cause of death in patients with CKD during IH. The cardiovascular risk in this group is consequence of hemodynamics changes the happen during IH. Structural cardiac diseases should be previously evaluated to perform IH because compromise cardiac function could be exacerbated during IH treatment $(30,31)$. For this reason, cardiac function was evaluated previous and after IH treatment. The patient's echodopplercardiography revealed moderate mitral insufficiency with overload of left chambers, left ventricular hypertrophy and presence of hyperechogenic content adhered to the atrium wall. Indeed, since the sheep had already cardiac structural abnormalities, cardiac evaluation after $\mathrm{IH}$ treatment was worse revealing a decrease in the systolic function and pulmonary artery flow, reduction of left chambers diameter, aggravation of left ventricular hypertrophy and enlargement of left atrioventricular valve's cuspids. As a result, the prognostic concerning survival was poorer because of the cardiomyopathy.

Finally, since the sheep died despite clinical improvement, post-mortem analysis was a fundamental to this case closure. Kidney's gross findings were suggestive of expressive interstitial glomerulonephritis, considering its pale cortex, red-colored corticomedullar junction and radial pale striations consistent to those described in the literature (19). Histological findings of glomerulosclerosis suggest that the sheep developed AKI, but already had a previous undiagnosed CKD. Glomerulosclerosis occurs after interstitial fibrosis and arteriolar hyalinosis, it represents the final and irreversible destruction of functioning nephrons (32).

\section{CONCLUSION}

Therefore, early prescription of intermittent hemodialysis still is the best renal replacement modality in cases of acute and acute-on-chronic kidney disease when conventional treatment does not respond. Furthermore, in our report, the ewe also had an undiagnosed insufficiency of both atrioventricular valves that was worsen, due to anesthesia, and myocarditis which despite of the improvement of the serum concentrations of serum BUN and creatinine by dialysis, lead to its to death. Hence, kidney diseases require further understanding to seek its etiology, which always relies in a full investigation of secondary comorbidities that worsen renal function.

\section{REFERENCES}

1. Verlander JW. Filtração glomerular. In: Klein BG. Cunnhingham tratado de fisiologia veterinária. 5a ed. Rio de Janeiro: Elsevier; 2014. p.460-8.

2. Bloom CA, Labato MA. Intermittent hemodialysis for small animals. Vet Clin North Am Small Anim Pract. 2011;41(1):115-3.

3. Cowgill LD. BUN kinetics and intermittent dialysis prescription in small animals. Vet Clin North Am Small Anim Pract. 2011;41(1):193-225.

Okamoto PTCG, Albiquerque, ALH, Geraldes SS, Vieira ANLS, Melchert A. Lourenço MLG. Intermittent hemodialysis, an alternative treatment for ovine with Acute-on-Chronic Kidney disease. Vet. e Zootec. 2020; 27 : 001-014. 
4. Smith BP. Disease of the renal system. In: Smith BP, Van Metre DC, Pusterla N. Large animal internal medicine. 6th ed. Missouri: Elsevier Health Sciences; 2019.

5. Santarosa BP, Ferreira DO, Belotta AF, Dias A, Mamprim MJ, Gonçalves RC. B-Mode and pulsed Doppler sonography of kidney in healthy sheep according to age. Pesqui Vet Bras. 2016;36(6):545-50.

6. Radostits OM, Gay CC, Blood DC, Hinchcliff KW. Veterinary medicine. 9th ed. London: WB Saunders; 2000.

7. Millar HR, Simpson JG, Stalker AL. An evaluation of the heat precipitation method for plasma fibrinogen estimation. J Clin Pathol. 1971; 24(9): 827-30.

8. Port FK, Ashby VB, Dhingra RK, Roys EC, Wolfe RA. Dialysis dose and body mass index are strongly associated with survival in hemodialysis patients. J Am Soc Nephrol. 2002;13(4):1061-6.

9. Bujok J, Walski T, Czerski A, Gałecka K, Grzeszczuk-kuć K, Zawadzki W, et al. Sheep model of haemodialysis treatment. Lab Anim. 2018;52(2):176-85.

10. Becker GJ, Hewitson TD. Animal models of chronic kidney disease: useful but not perfect". Nephrol Dial Transplant. 2013;28(10):2432-8.

11. Wong DM. Renal replacement therapy in healthy adult horses. J Vet Intern Med. 2013;27(2):308-16.

12. Wong DM. Use of renal replacement therapy in a neonatal foal with post-resuscitation acute renal failure. J Vet Intern Med. 2017;31(2):593-7.

13. Rabinowitz L, Gunther RA, Shoji ES, Freedland RA, Avery EH. Effects of high and low protein diets on sheep renal function and metabolism. Kidney Int. 1973;4(3):188-207.

14. Floeck M. Ultrasonography of bovine urinary tract disorders. Vet Clin North Am Food Anim Pract. 2009;25(3):651-67.

15. Scott PR. Clinical, ultrasonographic and pathological description of bladder distension with consequent hydroureters, severe hydronephrosis and perirenal fluid accumulation in two rams putatively ascribed to pelvic nerve dysfunction. Small Rumin Res. 2012;107(1):45-8.

16. Scott PR. Transabdominal ultrasonographic examination of 26 sheep with suspected urinary tract disease (2010-2012). J Vet Sci Med Diagn. 2013;2(1):1-5.

17. Ferreira DOL, Santarosa BP, Belotta AF, Mamprim MJ, Silva AA, Dias A, et al. Alterações ultrassonográficas renais e vesicais de ovinos confinados e suplementados com cloreto de amônio. Pesqui Vet Bras. 2014;34(1):99-106.

18. D’anjou MA, Penninck D. Atlas de ultrassonografia de pequenos animais. Rio de Janeiro: Guanabara Koogan; 2011. 
19. Zimmermann J, Herrlinger S, Pruy A, Metzger T, Wanner C. Inflammation enhances cardiovascular risk and mortality in hemodialysis patients. Kidney Int. 1999;5(2):648-58.

20. International Renal Interest Society - IRIS. IRIS grading of acute kidney injury (AKI) [Internet]. International Renal Interest Society; 2016 [cited 2019 Feb 6]. Available from: http://www.iris-kidney.com/pdf/IRIS_2017_Staging_of_CKD_09May18.pdf

21. Yerramilli M, Farace G, Quinn J. Kidney disease and the nexus of chronic kidney disease and acute kidney injury: the role of novel biomarkers as early and accurate diagnostics. Vet Clin North Am Small Anim Pract. 2016;46(6):961-93.

22. Stockham SL, Michael AS. Fundamentals of veterinary clinical pathology. 2nd ed. Ames: Blackwell Publishing; 2013.

23. Prause LC, Gregory FG. Association of gastrointestinal hemorrhage with increased blood BUN nitrogen and BUN/creatinine ratio in dogs: a literature review and retrospective study. Vet Clin Pathol. 1998;27(4):107-11.

24. Vaden SL, Elliott J. Management of proteinuria in dogs and cats with chronic kidney disease. Vet Clin North Am Small Anim Pract. 2016;46(6):1115-30.

25. Miller TR, Anderson RJ, Linas SL, Henrich WL, Berns AS, Gabow PA, et al. Urinary diagnostic indices in acute renal failure: a prospective study. Ann Intern Med. 1978;89(1):47-50.

26. De Loor J, Daminet S, Smets P, Maddens B, Meyer E. Urinary biomarkers for acute kidney injury in dogs. J Vet Intern Med. 2013;27(5):998-1010.

27. David DB, Poli CHEC, Savian JV, Amaral GA, Azevedo EB, Jochims F. Urinary creatinine as a nutritional and urinary volume marker in sheep fed with tropical or temperate forages. Arq Bras Med Vet Zootec. 2015;67(4):1009-15.

28. Lankadeva YR, Singh RR, Moritz KM, Parkington HC, Denton KM, Tare M. Renal dysfunction is associated with a reduced contribution of nitric oxide and enhanced vasoconstriction after a congenital renal mass reduction in sheep. Circulation. 2015;131(3):280-8.

29. Eschbach JW, Mladenovic J, Garcia JF, Wahl PW, Adamson JW. The anemia of chronic renal failure in sheep. Response to erythropoietin-rich plasma in vivo. J Clin Invest. 1984;74(2):434-41.

30. Barberato SH, Pecoits-Filho R. Alterações ecocardiográficas em pacientes com insuficiência renal crônica em programa de hemodiálise. Arq Bras Cardiol. 2010;94(1):131-7.

31. Barberato SH, Bucharles SG, Sousa AM, Costantini CO, Costantini CR, Pecoits-Filho R. Prevalência e impacto prognóstico da disfunção diastólica na doença renal crônica em hemodiálise. Arq Bras Cardiol. 2010;94(4):457-62. 
32. Chapman JR, Philip JO, Brian JN. Chronic renal allograft dysfunction. J Am Soc Nephrol. 2005;16(10):3015-302.

Recebido em: 20/02/2020

Aceito em: 10/12/2020

Okamoto PTCG, Albiquerque, ALH, Geraldes SS, Vieira ANLS, Melchert A. Lourenço MLG. Intermittent hemodialysis, an alternative treatment for ovine with Acute-on-Chronic Kidney disease. Vet. e Zootec. 2020; 27 : 001-014. 